\title{
Determinants of Subjective Well-Being: Evidence of Urban Indonesia
}

\section{Dewi Nandini*, Bambang Eko Afiatno}

Economics Department, Economic and Business Faculty, Airlangga University, Indonesia

* Corresponding author: dewinandini@gmail.com

\begin{tabular}{|c|c|}
\hline Artik & Abstrak \\
\hline $\begin{array}{l}\text { Article history: } \\
\text { Received March 25, } 2020 \\
\text { Revised May 09, } 2020 \\
\text { Accepted June 08, } 2020 \\
\text { Available online June 24, } \\
2020\end{array}$ & $\begin{array}{l}\text { Happiness studies on economics have increasingly arisen } \\
\text { since the uprising of the Easterlin Paradox phenomenon. } \\
\text { Besides its populous side, the urban area has more } \\
\text { complicated problems than rural. This research aims to } \\
\text { analyze the determinants of happiness in urban } \\
\text { Indonesia. We use the latest data from the Happiness } \\
\text { Measurement Survey } 2017 \text { conducted by the BPS- }\end{array}$ \\
\hline $\begin{array}{l}\text { Keyword: } \\
\text { Determinants; Happiness; } \\
\text { Ordered Logit; Subjective Well- } \\
\text { being. } \\
\text { JEL Classification; A13; } \\
\text { D60; I31. }\end{array}$ & $\begin{array}{l}\text { Statistic Agency of Indonesia. Taking } 30,665 \\
\text { observations, we apply the ordered logit estimation } \\
\text { technique (including G2-likelihood ratio test, Wald } \\
\text { statistical test, and Hosmer-Lemeshow goodness offit test) } \\
\text { to analyze the determinants of happiness. We found that } \\
\text { Easterlin Paradox does not exist in urban area Income, } \\
\text { education, health, marrying, internal-external } \\
\text { relationship, a satisfying job, positive feeling, and a } \\
\text { meaningful life have a positive impact on happiness. } \\
\text { Generally, these findings support some previous studies' } \\
\text { findings. }\end{array}$ \\
\hline
\end{tabular}

\section{INTRODUCTION}

Gross National Product (GNP) is well known as the most representative aggregate measure in depicting the country's prosperity (Frey \& Stutzer, 2018). For a long time, development progress has been more likely related to economic indicators such as income, poverty, and economic growth. Income and wellbeing have such a familiar connection in economics. The higher income level leads to a better quality of living facilities. Nevertheless, the idea that economic growth and income were not sufficient to represent development progress in a country, arose in the last few decades (Clark, 2018).

Diener and Seligman, (2004) stated that although the economy grew well in the last few decades, this growth was not followed by increasing life satisfaction in the same period. Easterlin, (1974) on his research in America found for the first time that increasing income is not followed by increasing happiness. This phenomenon was known as "Easterlin Paradox". Furthermore, some experts and government officials around the world not only began to realize the importance of measuring welfare that was not only based on income but also recommends the thoughts about measuring welfare in better ways (Forgeard et al, 2011). Johns and Ormerod, (2007) stated that we can not only assess human welfare materially, but also have to pay attention to the quality of relationships with others, the pleasant feeling because of sharing with others, the comfortable natural environment, and good governance. It is crucial to find a new welfare measure that not only based on economic but also tends to subjective well-being conditions (Forgeard et al., 2011; Frey \& Stutzer, 2018; Graham, 2011). 
Happiness research has increasingly developed by various experts, including economists. Economists focused the research on how happiness could be a proxy for the utility, which was the central concept of well-being (Graham, 2011). The utility concept is defined as a measure (numerical score) of the relative satisfaction level obtained by consumers from the consumption of goods and services (Pyndick and Rubinfeld, 2013; Sexton, Fortura, and Kovacs, 2016). In everyday life, we usually name a utility as a benefit or wellbeing (Pyndick and Rubinfeld, 2013). Subjectivity in utility concept allows someone to phrase their opinion about the happiness or satisfaction of their life (Frey and Stutzer, 2002).

Rather than ignoring macro indicators that have long been used in economic progress, happiness measure was expected to complement other macro indicators in measuring development progress which could be comparable across countries (Forgeard et al., 2011; Frey and Stutzer, 2018; Graham, 2011). Moreover, debates on happiness research also occurred in how happiness should be measured. Different research defined happiness differently so that it becomes vary and complicated to describe (Gasper, 2010), and bring a variety of terms up, such as quality of life, life satisfaction, and subjective wellbeing. Diener and Seligman, (2004) said that we need a more systematic approach to quantify happiness. However, some researchers did not mind this diversity and used them interchangeably.

Since the emergence of Easterlin's Paradox in 1974, interest in happiness research in economics has arisen rapidly (Frey and Stutzer, 2002). Governments all over the world are increasingly aware of and begin using happiness data in public policy decisions. Increased happiness can be considered as an appropriate indicator to measure social progress and public policy goals (Helliwell, Layard, and Sachs, 2015). The happiness studies in economics mostly analyze the determinants of happiness by using the ordered probit technique as an analysis tool.

Several researchers created studies on the determinants of happiness in Indonesia using the 2007 IFLS data, namely (Landiyanto et al., 2011; Sohn, 2010; Rahayu, 2016), and (Aryogi and Wulansari, 2016). The variables used in those studies were almost the same, but there were differences in the variables defining and observation numbers. In general, the results of the study are relatively similar, that a person will be happier if he has better health conditions, better educated, lives in an urban area, married, and has a higher income. Higher assets, better social relationships, and a sound government system also make someone happier. Meanwhile, age has U-shaped influences on happiness.

Research on the determinants of happiness in several countries has relatively more varied in the unit of observation. Research by (Chyi and Mao,2012) examined the determinants of happiness, which only focused on 1,533 Chinese residents aged 60 years and over. The study analyzed data from the 2005 Chinese General Social Survey using ordered probit techniques with instrumental variables. The elderly in China feel happier if they have high incomes, large houses, live in villages, and live with grandchildren. Another study by (Senasu and Singhapakdi, 2017) using telephone interview data based on a questionnaire developed by the Japan International Cooperation Agency, 
analyzed the happiness' determinants of 1,004 respondents in Thailand. The results show that younger, better educated, and high-income people tend to be happier. Also, health status influences happiness in more religious people.

Similar studies were also carried out by (Knight et al., 2009) and (Appleton and Song, 2008). Both studies analyzed the determinants of happiness in mainland China, but the focus and data sets used by those two studies were different. Knight et al. focus on rural Chinese populations while Appleton and Song focus on urban populations. Some of the same things from both studies are in both urban and rural areas one is happier if he has a higher income, is married, and has good social relations with his family and society. Other research by (Eren and Asici, 2017) includes a variable comparison of current life with the previous five years of life, a view of money (materialism attitude), and expectations of a future life as a proxy for psychological wellbeing. The results of this research indicate that materialistic attitudes lead to unhappiness. Conversely, someone tends to be happier if they have better hopes and expectations in the future.

In Indonesia, the BPS-Statistic Agency of Indonesia conducted Happiness Measurement Survey (called SPTK) in 2014 and 2017 by adapting the welfare measurement framework from the Organization of Economic Cooperation and Development (OECD). This survey describes the level of subjective happiness related to life aspects that are considered to be relevant and meaningful. These aspects contained three major dimensions: (1) evaluation of the ten domains of human life that are considered to be essential/important by the majority of the population, (2) affect (feelings or emotional conditions), and (3) eudaimonia (the meaning of life) (BPS, 2017). The 2017 SPTK samples are spread throughout provinces in Indonesia so that the data will be more representative in describing happiness in Indonesia.

We suppose that subjective well-being in Indonesia is still very interesting for further research. Several studies of happiness determinants in Indonesia have been carried out previously using data from the 2007 Indonesian Family Life Survey (IFLS). However, to the best of our knowledge, there has been no happiness research that uses the 2017 SPTK data from BPS, which focuses on urban. According to (BPS, 2017), 54.22 percent of Indonesia's residents are living in urban. In terms of employment, there would be excess labor which enhances unemployment. BPS, (2019) the recorded unemployment rate in urban is 6.45 percent, higher than rural which is 4.04 percent. Yet, the happiness index in urban is higher than in rural (BPS, 2017). In this study, we aim to analyze the determinants of subjective well-being (henceforth, we will use the term "happiness") in urban Indonesian.

\section{RESEARCH METHODS}

This research is a quantitative-based study by utilizing microdata from the Happiness Measurement Survey (Survei Pengukuran Tingkat Kebahagiaan/SPTK 2017) which contains 75,000 household samples. The SPTK 2017 is the second Happiness Measurement Survey conducted by the BPS-Statistic Agency of Indonesia, meanwhile, the first Happiness Measurement Survey was performed in 2014. BPS performed this survey to 
provide happiness data and calculate the happiness index in Indonesia. From these survey data sets, BPS had already calculated Indonesia's happiness index twice in 2014 and 2017. To the best of our knowledge, till May 2020 this research implied, BPS has not been conducted the same survey yet.

We prefer using micro-level data than macro-level data to make analyses more accurate. Microdata using mitigate biases which are usually occurred in the aggregation process. Besides that, we could not find any other more complete data sets even at the macro level. Indonesia's happiness data in the macro-level only contained basic information about the happiness index in each province. Another micro data set that contained information about subjective well-being was IFLS. The latest IFLS was the fifth wave (IFLS5) which was held in 2014/2015 and contains over 30,000 individuals living in 13 provinces in Indonesia. Meanwhile, 75,000 household samples of SPTK 2017 were spread out all over regencies/cities of 34 provinces in Indonesia. So, after comparing some advantages and disadvantages, we thought that SPTK 2017 was the most up to date data and strong enough to represent happiness conditions in Indonesia.

The observations in this study only focus on urban samples. From the overall responses sample, 30,665 observations that live in urban areas. We employ ordered logit estimation to answer the problem. The dependent variable in this study is "generally how happy the sample is." In the SPTK 2017 questionnaire, this question asks respondents to rate their overall happiness in life, by giving a score of $0-10$. A value of 0 indicates the worst condition, and 10 indicates the best condition. Simplifying the analysis, we reclassify the data into three categories (happy for a score of 6-10; so-so for a score of 5, and not happy for a score of 0-4). Furthermore, we will analyze 12 independent variables for their effects on happiness, they are 1) age, 2) marital status, 3) health status, 4) employment satisfaction, 5) education, 6) homeownership, 7) monthly household income, 8) family harmony, 9) social relationships, 10) environmental conditions, and 11) meaning of life.

Variable age and age squares are ratio scaled, which refer to the respondent's last birthday. We include quadratic elements to the model to see whether the age affects U-shaped, like the majority of previous studies. Marital status is divided into two, married and single - the single consists of respondents who are single and divorced. The respondent's health condition represents the intensity of experiencing physical disorders due to symptoms of the disease, which is categorized as healthy (never/rarely) and unhealthy (often/highly often). Meanwhile, education refers to the highest level of education completed by respondents. This variable is categorized as less than junior high school, senior high school, and senior high school above. Respondent's satisfaction of employment consists of respondent's assessment of distance, place, social environment, wage, and conformity of their job. We use this variable rather than employment status because it can represent all things about respondents' job. Homeownership is ownership of residential buildings occupied by respondents and their households, which are categorized as their own and not their own. 
Furthermore, we combine family relationships, social relationships, and environmental conditions into variable inex, which represent the mean value of those three variables. Family relationships represent respondents' satisfaction with the harmony of their families. In this variable, family harmony includes three things, cohesiveness, trust in the family, and sufficient time for joint activities. Social relationships are respondents' satisfaction with relationships with the surrounding community. This social relationship is related to harmony and the opportunity to socialize with residents around the respondent's residence. Environmental conditions indicate respondents' satisfaction with the environmental conditions of their homes, which include water quality, air quality, and disasters.

Moreover, the effect is respondents' assessment of their positive and stable feelings which not easily change in a short time (consist of happy, worried, and depressed feeling). The meaning of life is the respondent's assessment of the meaning of life. It includes independence, environmental mastery, self-development, positive relationships with others, life goals, and self-acceptance. On these three variables, the respondent was asked to give a score of $0-10$, which illustrates his perception. However, in this research, these three variables will be categorized binary (code 0 for score $0-5$, and code 1 for score 6-10). All variables used in this research are shown in Table 1.

We apply the ordered logit method because it allows modeling in case the dependent variable has more than two ordered categories, and use Stata 13.0 software to process the data. Generally, the model can be written as follows:

$\ln \left(\frac{\sum_{j=1}^{k} p_{j}}{1-\sum_{j=1}^{k} p_{j}}\right)=\beta_{0}+\beta_{1 j}$ age $+\beta_{2 j}$ age $e^{2}+\beta_{3 j}$ married $+\beta_{4 j}$ education $_{1}+$ $\beta_{5 j}$ education $_{2}+\beta_{6 j}$ health $+\beta_{7 j}$ jobsatisfaction $+\beta_{8 j}$ income $_{1}+$ $\beta_{9 j}$ income $_{2}+\beta_{10 j}$ income $_{3}+\beta_{11 j}$ income $_{4}++\beta_{12 j}$ home $+\beta_{13 j}$ inex + $\beta_{14 j}$ affect $+\beta_{15 j}$ meaningfullife $+\varepsilon$

Where $\mathrm{j}=1,2, \ldots, \mathrm{k}(\mathrm{k}=$ number of category of dependent variable)

In ordered logit estimation, we use the marginal effect value for interpreting the model. The marginal effect is the change in the probability value of dependent variables when independent variable moves, assuming the other variables are fixed. In the logit model, the marginal effect of $x_{j}$ is written as follows:

$\frac{\partial \pi\left(x_{i}\right)}{\partial x_{j}}=\pi\left(x_{i}\right) \cdot\left(1-\pi\left(x_{i}\right)\right) \cdot \beta_{j}$

Where $\beta_{j}$ is the coefficient of independent variables $j$ 
Table 1. Variable's Operational Definitions and Categorization

\begin{tabular}{|c|c|c|}
\hline Variables & Definition & Categorization \\
\hline Happiness (happy) & $\begin{array}{l}\text { Respondent's assessment } \\
\text { of general happiness in } \\
\text { life }\end{array}$ & $\begin{array}{l}0=\text { unhappy (base) } \\
1=\text { so-so } \\
2=\text { happy }\end{array}$ \\
\hline Age $\left(a g e, a g e^{2}\right)$ & $\begin{array}{l}\text { Respondent's age } \\
\text { according to the last } \\
\text { birthday }\end{array}$ & - \\
\hline $\begin{array}{l}\text { Marital status } \\
\text { (married) }\end{array}$ & $\begin{array}{l}\text { Respondent's marital } \\
\text { status }\end{array}$ & $\begin{array}{l}0=\text { no }(\text { base }) \\
1=\text { yes }\end{array}$ \\
\hline $\begin{array}{l}\text { Education } \\
\text { (education) }\end{array}$ & $\begin{array}{l}\text { Respondent's highest } \\
\text { completed education } \\
\text { level }\end{array}$ & $\begin{array}{l}0=\leq \text { junior high school } \\
\text { (base) } \\
1=\text { senior high school } \\
2=>\text { senior high school }\end{array}$ \\
\hline $\begin{array}{l}\text { Health status } \\
\text { (health) }\end{array}$ & $\begin{array}{l}\text { The intensity of health } \\
\text { problems for the past six } \\
\text { months }\end{array}$ & $\begin{array}{l}0=\text { often } / \text { highly often } \\
\text { (base) } \\
1=\text { never/rarely }\end{array}$ \\
\hline $\begin{array}{l}\text { Employment } \\
\text { satisfaction (job } \\
\text { satisfaction) }\end{array}$ & $\begin{array}{l}\text { Respondent's } \\
\text { satisfaction of a job }\end{array}$ & $\begin{array}{l}0=\text { not satisfied (base) } \\
1=\text { satisfied }\end{array}$ \\
\hline $\begin{array}{l}\text { Household } \\
\text { income (income) }\end{array}$ & $\begin{array}{l}\text { Total income (money } \\
\text { and goods) obtained by } \\
\text { all household members } \\
\text { (in Rupiah) }\end{array}$ & $\begin{array}{l}0=\leq 1,800,000 \text { (base) } \\
1=1,800,001-3,000,000 \\
2=3,000,001-4,800,000 \\
3=4,800,001-7,200,000 \\
4=>7,200,000\end{array}$ \\
\hline $\begin{array}{l}\text { Homeownership } \\
\text { (home) }\end{array}$ & $\begin{array}{l}\text { Ownership of residential } \\
\text { buildings occupied by } \\
\text { respondents and their } \\
\text { households }\end{array}$ & $\begin{array}{l}0=\text { not their own (base) } \\
1=\text { their own }\end{array}$ \\
\hline $\begin{array}{l}\text { Internal and } \\
\text { external condition } \\
\text { (inex) }\end{array}$ & $\begin{array}{l}\text { Respondent's } \\
\text { satisfaction of family } \\
\text { harmony, social } \\
\text { relationship, and } \\
\text { environmental condition }\end{array}$ & $\begin{array}{l}0=\text { not satisfied (base) } \\
1=\text { satisfied }\end{array}$ \\
\hline Affect (affect) & $\begin{array}{l}\text { Respondent's assessment } \\
\text { of their stable feeling } \\
\text { (not a momentary } \\
\text { emotion/not easily } \\
\text { change in a short time) }\end{array}$ & $\begin{array}{l}0=\text { not satisfied (base) } \\
1=\text { satisfied }\end{array}$ \\
\hline $\begin{array}{l}\text { Meaning of life } \\
\text { (meaningful life) }\end{array}$ & $\begin{array}{l}\text { Respondent's assessment } \\
\text { of their meaning of life }\end{array}$ & $\begin{array}{l}0=\text { meaningless }(\text { base }) \\
1=\text { meaningful }\end{array}$ \\
\hline
\end{tabular}

We need to test simultaneously and partially whether the model is meaningful or not. The simultaneous test is used to determine whether all independent variables together affect the dependent variable, using the $\mathrm{G}^{2}$ statistical test (likelihood ratio test). The partial test is used to determine 
whether each independent variable affects the dependent variable, using the Wald statistical test. Moreover, we also test the goodness of fit of the model by using the Hosmer-Lemeshow goodness of fit test.

\section{RESULT AND DISCUSSION}

This research aims to analyze what factors determine the happiness of Indonesian urban, using ordered logit estimation. We analyze 30,665 observations of the 2017 SPTK data using Stata 13.0. BPS conducted the SPTK for providing happiness data and forming a happiness index in Indonesia. The index is expressed on a scale of 0-100. So far, BPS has released the happiness index twice in 2014 and 2017. The method used in preparing the 2017 happiness index in different from those used in the 2014 happiness index. In 2014, the happiness index was only based on life satisfaction dimensions. Meanwhile, the 2017 happiness index is formed from three dimensions, 1) the life satisfaction dimension, 2) the effect dimension (feeling/emotional), and 3) the meaning of life dimension. According to (BPS, 2017). Indonesia's happiness index in 2017 is 70.69. North Maluku has the highest happiness index, which is 75.68, meanwhile Papua has the lowest one, which is 67.52.

Table 2 shows the respondents' characteristics of this research. Descriptively, according to Table 1, most Indonesian urban seems to be happy. Even though the highest percentage occurred on "happy", but we can still see the different patterns on each independent variable. In terms of income, the lower-income showed a higher percentage of unhappy and so-so occurrence. This represents that money has strong power on affecting happiness in Indonesian urban. About 78 percent of urban have good health and own their house. We can see that healthier respondents and homeownership make a bigger percentage of a happy moment.

About 95.65 percent of married respondents are happy, and about 92.09 percent of single are happy. Although the difference is small, we can see that marrying tend to give happiness to Indonesian urban. In the case of education, 50 percent of respondents have passed junior high school and lower, even though most of them are happy. We also see that at the higher education level, the percentage of happy respondents is higher too, so that we can say that education seems to be an essential factor in affecting the happiness of Indonesian urban. Talking about the job, the data show that about 75.45 percent of urban are not satisfied with their job. But, most of them are still happy with their life. This job dissatisfaction may be caused by a far workplace, unpleasant work atmosphere, interest mismatch, or inappropriate wages. If we connect it with education level, there will be more low-quality labors than highquality ones. Therefore, there will be more workers occupied in low skill jobs. 
Table 2. Respondents' Characteristics

\begin{tabular}{|c|c|c|c|c|c|}
\hline Variables & Category & \multicolumn{4}{|c|}{ Sample Distribution (Percent) } \\
\hline \multirow{3}{*}{ happy } & unhappy & \multicolumn{4}{|c|}{2.12} \\
\hline & so-so & \multicolumn{4}{|c|}{2.94} \\
\hline & happy & \multicolumn{4}{|c|}{94.93} \\
\hline \multirow[b]{2}{*}{ Independen } & \multirow{2}{*}{ Variables } & \multirow{2}{*}{$\begin{array}{l}\text { Sample } \\
\text { Distribu } \\
\text { tion (\%) }\end{array}$} & \multicolumn{3}{|c|}{ Happiness } \\
\hline & & & Unhappy & So-So & Happy \\
\hline \multirow{5}{*}{ income } & $\begin{array}{l}<= \\
1.800 .000\end{array}$ & 22.70 & 4.97 & 5.72 & 89.31 \\
\hline & $\begin{array}{l}1.800 .001- \\
3.000 .000\end{array}$ & 26.65 & 2.12 & 3.12 & 94.76 \\
\hline & $\begin{array}{l}3.000 .001- \\
4.800 .000\end{array}$ & 21.47 & 1.26 & 2.14 & 96.60 \\
\hline & $\begin{array}{l}4.800 .001- \\
7.200 .000\end{array}$ & 15.29 & 0.70 & 1.34 & 97.95 \\
\hline & $>7.200 .001$ & 13.89 & 0.38 & 1.08 & 98.54 \\
\hline \multirow{2}{*}{ health } & $\begin{array}{l}\text { often/highly } \\
\text { often }\end{array}$ & 22.25 & 3.85 & 4.85 & 91.30 \\
\hline & never/rarely & 77.75 & 1.63 & 2.40 & 95.97 \\
\hline \multirow[t]{2}{*}{ home } & $\begin{array}{l}\text { not their } \\
\text { own }\end{array}$ & 22.25 & 3.85 & 4.85 & 91.30 \\
\hline & their own & 77.75 & 1.63 & 2.40 & 95.97 \\
\hline \multirow{2}{*}{ married } & $\begin{array}{l}\text { single/divor } \\
\text { ced }\end{array}$ & 20.03 & 3.22 & 4.69 & 92.09 \\
\hline & married & 79.97 & 1.85 & 2.51 & 95.65 \\
\hline \multirow{3}{*}{ education } & $\begin{array}{l}\leq \text { junior high } \\
\text { school }\end{array}$ & 50.03 & 3.29 & 4.13 & 92.58 \\
\hline & $\begin{array}{l}\text { senior high } \\
\text { school }\end{array}$ & 33.41 & 1.23 & 2.12 & 96.65 \\
\hline & $\begin{array}{l}>\text { senior } \\
\text { high school }\end{array}$ & 16.56 & 0.39 & 1.02 & 98.58 \\
\hline \multirow{2}{*}{ jobsatisfaction } & not satisfied & 75.45 & 2.42 & 3.38 & 94.20 \\
\hline & satisfied & 24.55 & 1.20 & 1.61 & 97.20 \\
\hline \multirow{2}{*}{ inex } & not satisfied & 2.97 & 15.15 & 17.78 & 67.07 \\
\hline & satisfied & 97.03 & 1.72 & 2.49 & 95.79 \\
\hline \multirow{2}{*}{ affect } & negative & 7.36 & 13.96 & 12.77 & 73.27 \\
\hline & positive & 92.64 & 1.18 & 2.16 & 96.65 \\
\hline \multirow{2}{*}{ meaningfullife } & meaningless & 4.17 & 16.34 & 20.33 & 63.33 \\
\hline & meaningful & 95.83 & 1.50 & 2.19 & 96.31 \\
\hline \multirow[b]{2}{*}{ age } & Mean & \multicolumn{4}{|c|}{46.15} \\
\hline & $\begin{array}{l}\text { Std. } \\
\text { Deviation }\end{array}$ & \multicolumn{4}{|c|}{13.41} \\
\hline
\end{tabular}

Source: The 2017 SPTK, processed

Moreover, most respondents have a satisfying relationship with family, society, and environment. Most respondents also have a satisfying effect and feel meaningful in their life. These mean that Indonesian urban are well adapted to an urban hard life. They can control positive and negative emotions, and also have a good spirit to live. From the data, we can see that these three variables 
affect urban's happiness a lot. Respondents with dissatisfied internal-external relationship show a relatively big percentage of the unhappy and so-so outcome, which are about 15.15 and 17.78 percent. This is also happened to the two other variables, affect, and meaningful life. About 13.96 percent and 12.77 percent of respondents with dissatisfied effects tend to answer unhappy and so-so. Furthermore, about 16.34 percent and 20.33 percent of respondents with meaningless life reported they are unhappy and so-so.

Table 3 shows the result of ordered logit estimation which is used to see what independent variables affect happiness. The simultaneous test shows a significant probability value ( $p$-value) $(<0.01)$, which means the whole independent variable influences the dependent variable. The Pseudo- $R^{2}$ value indicates the simultaneous effects of the independent variables on the dependent variable. The test shows the value of 0.2126 , which means that all independent variables give an effect of 21.60 percent to the dependent variable, while other variables influence the remaining 78.40 percent. The partial test also shows that all independent variables give significant results, which indicates that each independent variable included in the model affects the dependent variable. Moreover, the goodness of fit test also shows that the estimation model is fit/good to the data. Meanwhile, Table 4 shows the marginal effect of independent variables on each category of happiness.

Happiness research on economic mostly includes income indicators. The estimation shows that household income has a positive impact on happiness. The higher income leads to a happier condition. From this finding, we also see that Easterlin Paradox does not exist in urban Indonesia, and income is still a strong factor that affects the respondent's happiness. Frey and Stutzer (2018) stated that some researches in Japan, Italy, and West Europe showed the increasing happiness as GNP increased. This finding also supports some previous studies, including (Sohn, 2010; Rahayu, 2016; Appleton and Song, 2008; Chyi and Mao, 2012), also (Eren and Asici, 2017). However, (Johns and Ormerod, 2007) stated that at a certain point, the increase in happiness will be smaller as income increases. Also, materialistic leads to unhappiness (Eren \& Aș1c1, 2017; Frey \& Stutzer, 2018).

According to (Oswald and Powdthavee, 2008), healthier people are consistently more likely to be happier. The estimation shows that health has a positive impact on happiness. Respondents that never/rarely have health problem are 0.28 percent less likely to be unhappy and 0.79 percent more likely to be happy than those who are frequently sick. This result is in line with the findings of (Frijters et.al, 2004; Landiyanto et.al, 2011), and Sohn (2010). Frey and Stutzer (2018) explain that someone's subjective good health has a stronger correlation with happiness than objective health which issued medically by a doctor because each person has different ways to respond to his health condition. A sick person usually compares his condition to others with the worse condition.

Furthermore, marital status also shows a positive impact on happiness. Marrying respondents are 0.3 percent less likely and 0.96 percent more likely to be happy than those who are single or divorced. Frey and Stutzer (2018) noted that marriage can mitigate depressed feelings because of loneliness and hard 
work. Economically, marriage not only provides financial guarantees in a bad economic period but also provide higher capital accumulation (Stutzer \& Frey, 2006). However, the happiness benefit of marriage assumes "happy marriage" (Sirgy et al., 2012). People who are not happily married are more likely to report physical health and psychological problem (DeLongis, Folkman, \& Lazarus, 1988).

Table 3. Ordered Logit Estimation Result

\begin{tabular}{|c|c|c|c|}
\hline Variables & Category & Coeff. & Std. Error \\
\hline \multirow[t]{3}{*}{ happy } & $0=$ unhappy (base) & & \\
\hline & $1=$ so-so $($ cut 1$)$ & -0.3669 & 0.3224 \\
\hline & $2=$ happy (cut 2$)$ & 0.7185 & 0.3221 \\
\hline \multirow[t]{5}{*}{ income } & $0=<=1.800 .000$ (base) & & \\
\hline & $1=1.800 .001-3.000 .000$ & $0.3216^{* * *}$ & 0.0707 \\
\hline & $2=3.000 .001-4.800 .000$ & $0.4981^{* * *}$ & 0.0881 \\
\hline & $3=4.800 .001-7.200 .000$ & $0.7952 * * *$ & 0.1215 \\
\hline & $4=>7.200 .001$ & $0.9757 * * *$ & 0.1488 \\
\hline \multirow[t]{2}{*}{ health } & $\begin{array}{l}0=\text { often/highly often } \\
\text { (base) }\end{array}$ & & \\
\hline & $1=$ never $/$ rarely & $0.2763 * * *$ & 0.0622 \\
\hline \multirow[t]{2}{*}{ home } & $0=$ not their own (base) & & \\
\hline & $1=$ their own & $0.1632^{* *}$ & 0.0672 \\
\hline age & - & $-0.0870 * * *$ & 0.0129 \\
\hline age2 & - & $0.0009 * * *$ & 0.0001 \\
\hline \multirow[t]{2}{*}{ married } & $0=$ single $/$ divorced (base) & & \\
\hline & $\begin{array}{l}1=\text { married } \\
0=\leq \text { junior high school } \\
\text { (base) }\end{array}$ & $0.3302 * * *$ & 0.0681 \\
\hline \multirow{2}{*}{ education } & $1=$ senior high school & $0.3824^{* * *}$ & 0.0721 \\
\hline & $2=>$ senior high school & $0.7114^{* * *}$ & 0.1352 \\
\hline \multirow{2}{*}{$\begin{array}{l}\text { job } \\
\text { satisfaction }\end{array}$} & $0=$ not satisfied (base) & & \\
\hline & $1=$ satisfied & $0.4189 * * *$ & 0.0404 \\
\hline \multirow[t]{2}{*}{ inex } & $0=$ not satisfied (base) & & \\
\hline & $1=$ satisfied & $1.3729 * * *$ & 0.0887 \\
\hline \multirow[t]{2}{*}{ affect } & $0=$ not satisfied (base) & & \\
\hline & $1=$ satisfied & $1.6927 * * *$ & 0.048 \\
\hline \multirow{2}{*}{$\begin{array}{l}\text { meaningful } \\
\text { life }\end{array}$} & $0=$ not satisfied (base) & & \\
\hline & $1=$ satisfied & $1.7154^{* * *}$ & 0.0744 \\
\hline \multicolumn{2}{|c|}{ Number of observations } & & 30,665 \\
\hline \multicolumn{2}{|c|}{ Pseudo $\mathrm{R}^{2}$} & & 0.2078 \\
\hline \multicolumn{2}{|c|}{ Goodness of fit test ( $p$-value) } & 0.6726( & nodel is fit) \\
\hline \multicolumn{2}{|c|}{ Correctly classified percentage } & & 97.79 \\
\hline \multicolumn{2}{|c|}{$\begin{array}{l}\text { Source: The } 2017 \text { SPTK, processed } \\
\text { Note: *** significant at } 1 \text { percent; }{ }^{* *} \text { significant at } 5 \text { percent; }\end{array}$} & & \\
\hline
\end{tabular}


Age seems to affect happiness U-shaped, and it supports some previous studies (Appleton and Song, 2008; Rahayu, 2016; Knight et.al, 2009; and Sohn, 2010). Sohn (2010) found that in Indonesia, the bottom of the curve is at 62 years old, but it is rather late compared to other studies that have a turning point at the '50s. Frey and Stutzer (2018) explain that at the middle age, decreasing happiness is mostly caused by life pressures and problems, such as the difficulties in having a good career or having a good wealth. But, happiness increases when someone is getting older, because finally, he realizes that he can't reach all targets and just enjoy anything he has. However, (Frijters and Beatton, 2012) find that the age-happiness relationship does not look like Ushape but looks like a "late-wave", that relative to 20 years old, there is not much change in happiness till around 55, and then start to increase till around 67 , and start declining around 75 . One of their explanation of this phenomenon is life become stress-free around 60, and there is a big health decline after 75 .

Meanwhile, homeownership also has a positive impact on happiness. Respondents who have their homes are 0.16 percent less likely to be unhappy and 0.45 percent more likely to be happy. This finding is in line with the findings of (Chyi and Mao, 2012). Compared to those who still rent a house, homeownership can increase confidence, pride, and safe feeling (Diaz-Serrano, 2009; Guven \& Sørensen, 2012; Hu, 2013; Shlay, 2006). But, on the other side, homeownership also hurts happiness if the owner bears a high housing cost or a big depreciation value (Elsinga \& Hoekstra, 2005; Parker, Watson, \& Webb, 2011). Besides cost, mobility, and flexibility limitations also tend to lower happiness.

The level of education also shows a positive and significant impact on happiness. The higher level of education leads to a happier condition because it generally leads to better opportunities and broader networks in employment (Chen, 2012; Frey \& Stutzer, 2018). Respondents who graduated senior high school are 0.34 percent less likely to be unhappy and 0,96 percent more likely to be happy. Furthermore, respondents who graduated from college are 0.54 percent less likely to be unhappy and 0.15 percent more likely to be happy. Sirgy et al. (2012) explain that education could contribute to happiness and could be damage to happiness too. On the positive side, education could be a resource to help in reaching life goals. But on the negative side, education could raise people's aspirations too high to the point that makes impossible life goals.

Moreover, a satisfying job also has a positive impact on happiness. Respondents who satisfied with their jobs are 0.39 percent less likely to be unhappy and 0.11 percent are likely to be happy. Some previous studies show that unemployment reported lower happiness than those who have a job (Blanchflower, Bell, Montagnoli, \& Moro, 2014; Kalyuzhnova \& Kambhampati, 2008; Knight et al., 2009; Sohn, 2010). Frey and Stutzer (2018) argued that psychologically unemployment may lose self-confidence and feel exiled in their neighborhood. The satisfying job usually depends on the job type. Self-employment generally feels happier than laborers, because they have more pride, freedom, and feeling of achievement (Di Tella, MacCulloch, \& Oswald, 2001; Frey \& Stutzer, 2018). However, self-employment faces a risk of failure, has a long time work, and bigger stress (Van Der Hulst, 2003). 
Table 4. Marginal Effect of Independent Variables on Each Category of Happiness

\begin{tabular}{|c|c|c|c|c|c|c|}
\hline \multirow{2}{*}{$\begin{array}{c}\text { Independent } \\
\text { Variables }\end{array}$} & \multicolumn{2}{|c|}{ Unhappy } & \multicolumn{2}{|c|}{ So-So } & \multicolumn{2}{|c|}{ Happy } \\
\hline & $\mathrm{dy} / \mathrm{dx}$ & SE & $\mathrm{dy} / \mathrm{dx}$ & SE & $\mathrm{dy} / \mathrm{dx}$ & $\mathrm{SE}$ \\
\hline \multicolumn{7}{|l|}{ income } \\
\hline $\begin{array}{l}1=1.800 .001 \\
-3.000 .000\end{array}$ & -0.0028 & 0.0006 & -0.0052 & 0.0011 & 0.0080 & 0.0016 \\
\hline $\begin{array}{l}2=3.000 .001 \\
-4.800 .000\end{array}$ & -0.0041 & 0.0006 & -0.0075 & 0.0012 & 0.0116 & 0.0018 \\
\hline $\begin{array}{l}3=4.800 .001 \\
-7.200 .000\end{array}$ & -0.0058 & 0.0007 & -0.0108 & 0.0013 & 0.0166 & 0.0020 \\
\hline $\begin{array}{l}4=> \\
7.200 .001\end{array}$ & -0.0067 & 0.0007 & -0.0124 & 0.0013 & 0.0191 & 0.0021 \\
\hline health & -0.0028 & 0.0007 & -0.0051 & 0.0012 & 0.0079 & 0.0019 \\
\hline home & -0.0016 & 0.0007 & -0.0029 & 0.0012 & 0.0045 & 0.0019 \\
\hline age & 0.0008 & 0.0001 & 0.0015 & 0.0002 & -0.0023 & 0.0004 \\
\hline age $^{2}$ & -0.0000 & 0.0000 & -0.0000 & 0.0000 & 0.0000 & 0.0000 \\
\hline $\begin{array}{l}\text { married } \\
\text { education }\end{array}$ & -0.0034 & 0.0008 & -0.0062 & 0.0014 & 0.0096 & 0.0022 \\
\hline $\begin{array}{l}1=\text { senior } \\
\text { high school }\end{array}$ & -0.0034 & 0.0006 & -0.0062 & 0.0011 & 0.0096 & 0.0017 \\
\hline $\begin{array}{l}2=>\text { senior } \\
\text { high school }\end{array}$ & -0.0054 & 0.0008 & -0.0099 & 0.0015 & 0.0153 & 0.0023 \\
\hline satisfyingjob & -0.0039 & 0.0004 & -0.0072 & 0.0008 & 0.0111 & 0.0011 \\
\hline inex & -0.0258 & 0.0030 & -0.0439 & 0.0044 & 0.0697 & 0.0076 \\
\hline affect & 0.0354 & 0.0028 & 0.0589 & 0.0041 & 0.0942 & 0.0064 \\
\hline meaningfullife & -0.0382 & 0.0035 & -0.0629 & 0.0051 & 0.1011 & 0.0082 \\
\hline
\end{tabular}

Source: The 2017 SPTK, processed

The internal and external conditions give a positive impact on happiness. Respondents who have satisfying relationships in family, society, and environmental are 0.39 percent less likely to be unhappy and 0.11 percent more likely to be happy. Good relationships within family and society are an essential side which influences happiness (Frey \& Stutzer, 2018; Knight et al., 2009; Sohn, 2010). Also, an excellent relationship is a source of social capital, a form of human relationship which can influence community productivity (BPS, 2016). Besides, environmental feasibility represents environmental quality where people can get everything they need, so that environment is an essential thing that affects happiness (Veenhoven, 2000). (Sirgy et al., 2012) stated some theories about relationships that relate to happiness, which are 1) the need to belong; 2) attachment; 3) the buffering effect of the family; 4) bottom-up spillover; 5) horizontal spillover; 6) compensation; 7) mattering.

The next two variables, affect and meaningful life, is the proxy for psychological well-being. Both affect and meaningful life has positive effects on happiness. Conigliaro (2018) explain that emotional condition could be positive forms (trust, happiness, pleasure) or a negative form (worries, fear). Respondents who have a satisfying effect are 0.35 percent less likely to be 
unhappy and 0.94 percent more likely to be happy. Hills and Argyle (2001) conclude that emotional stability has a strong correlation to happiness, life satisfaction, and self-esteem. Bradburn in Hills and Argyle (2001) also stated that those who have a bigger positive effect would have a higher degree of psychological well-being than those who have a bigger negative affect in life. Meanwhile, (Ryff in Sirgy et al, 2012) explain six dimensions of psychological well-being, which are 1) self-acceptance; 2) positive relationship with others; 3 ) self-development; 4) life goals; 5) environmental mastery; 6) autonomy. Furthermore, respondents who have a meaningful life are 0.38 percent less likely to be unhappy and 1.01 percent more likely to be happy. This finding also supports (Eren and Asici, 2017) who found that expectations for better future influence happiness.

\section{CONCLUSION}

This study aims to examine the determinants of happiness in Indonesian urban. We found that the factors that can increase the probability of happiness in urban Indonesia are higher education, higher income, better health, own a house, satisfying job, satisfying internal-external relationship, having a positive feeling (affect), and psychologically feel meaningful in life. Meanwhile, age affects happiness in the U-shaped. These findings also support some previous findings in happiness studies.

Attention to happiness becomes essential for policymakers because happiness is expected to be a measure that can complement other macroeconomic indicators to reflect the country's achievement. Health and education are still essential aspects that the community and government must pay attention to them. The data show that half of the respondents are low educated. Education facilities are more sophisticated in urban, but they are usually unreachable by middle-lower-income people. The central and regional governments can guarantee the availability of qualified and affordable health and education facilities so that they can develop the quality of human resources, especially in urban. In a better quality of education, there will be more qualified workers. However, the community must also be responsible for maintaining health with a healthy lifestyle and nutritious food.

The urban area has more complicated and dynamic conditions than rural. The urban area is not only more populous but also undeniable that it has a severe problem in the environment feasibility, especially in the capital city. An overcrowded environment always leads to an abundance of garbage, which can lead to floods and pollutions. Moreover, it also requires joint efforts to maintain family harmony and good social relationship. Good social relationships will foster social capital in the community and create a more productive community in supporting development.

One limitation of this research lies in the data used. 2017 SPTK data does not reflect the happiness of each individual. This problem makes 2017 SPTK less representative for a more specific analysis of happiness. BPS may review the possibility to take individual information about happiness in the same survey, or combine them to other surveys which allow the interview to each individual. Another limitation of this study is the use of cross-section data, 
so there is no way to see the trend of happiness in Indonesia. For further research, we suggest using time-series data if available so that we can see the trend of happiness in Indonesia.

\section{REFERENCES}

Appleton, S., \& Song, L. (2008). Life Satisfaction in Urban China: Components and Determinants. World Development, 36(11), 2325-2340. https://doi.org/10.1016/j.worlddev.2008.04.009

Aryogi, I., \& Wulansari, D. (2016). Subjective Well-being Individu dalam Rumah Tangga Di Indonesia. Jurnal Ilmu Ekonomi Terapan, 01(1), 1-12.

Blanchflower, D. G., Bell, D. N. F., Montagnoli, A., \& Moro, M. (2014). The Happiness Trade-Off Between Unemployment and Inflation. Journal of Money, Credit and Banking, 46(S2), 117-141. https://doi.org/10.1111/jmcb.12154

BPS. (2016). Statistik Modal Sosial 2014. Jakarta.

BPS. (2017). Indeks kebahagiaan 2017. Jakarta: Badan Pusat Statistik.

BPS. (2019). Statistik Indonesia 2019. Jakarta: Badan Pusat Statistik.

Chen, W. chi. (2012). How Education Enhances Happiness: Comparison of Mediating Factors in Four East Asian Countries. Social Indicators Research, 106(1), 117-131. https://doi.org/10.1007/s11205-011-9798-5

Chyi, H., \& Mao, S. (2012). The Determinants of Happiness of China's Elderly Population. Journal of Happiness Studies, 13(1), 167-185. https://doi.org/10.1007/s10902-011-9256-8

Clark, A. E. . et. a. (2018). The Origins of Happiness : The Science of Well-Being over The Life Course. https://doi.org/10.1017/CBO9781107415324.004

Conigliaro, P. (2018). Labour Status and Subjective Well-being A Micro-level Analysis and a Labour Status and Subjective Well-being A Micro-level Analysis and a Multidimensional Approach to Well-being (No. 4). Roma.

DeLongis, A., Folkman, S., \& Lazarus, R. S. (1988). The Impact of Daily Stress on Health and Mood: Psychological and Social Resources as Mediators. Journal of Personality and Social Psychology, 54(3), 486-495. https://doi.org/10.1037/0022-3514.54.3.486

Di Tella, R., MacCulloch, R. J., \& Oswald, A. J. (2001). Preferences over inflation and unemployment: Evidence from surveys of happiness. American Economic Review, 91(1), 335-347. https://doi.org/10.1257/aer.91.1.335

Diaz-Serrano, L. (2009). Disentangling the housing satisfaction puzzle: Does homeownership really matter? Journal of Economic Psychology, 30(5), 745755. https://doi.org/10.1016/j.joep.2009.06.006

Diener, E., \& Seligman, M. E. P. (2004). Beyond Money: Toward an Economy of Well-Being. Psychological Science in the Public Interest, 5(1), 1-31. https://doi.org/10.1111/j.0963-7214.2004.00501001.x

Easterlin, R. A. (1974). Does Economic Growth Improve the Human Lot? Some Empirical Evidence. In Nations and Households in Economic Growth. https://doi.org/10.1016/b978-0-12-205050-3.50008-7

Elsinga, M., \& Hoekstra, J. (2005). Homeownership and housing satisfaction. Journal of Housing and the Built Environment, 20(4), 401-424. 
https://doi.org/10.1007/s10901-005-9023-4

Eren, K. A., \& Așıc1, A. A. (2017). The Determinants of Happiness in Turkey: Evidence from City-Level Data. Journal of Happiness Studies, 18(3), 647669. https://doi.org/10.1007/s10902-016-9746-9

Forgeard, M. J. C., Jayawickreme, E., Kern, M. L., \& Seligman, M. E. P. (2011). Doing the right thing: Measuring wellbeing for public policy. 1, 79-106. https://doi.org/10.5502/ijw.v1i1.15

Frey, B. S., \& Stutzer, A. (2002). What Can Economists Learn from Happiness Research? Journal of Economic Literature, 40, 402-435. https://doi.org/10.1257/jel.40.2.402

Frey, B. S., \& Stutzer, A. (2018). Economics of Happiness. Springer International Publishing.

Frijters, P., \& Beatton, T. (2012). The mystery of the U-shaped relationship between happiness and age. Journal of Economic Behavior and Organization, 82(2-3), 525-542. https://doi.org/10.1016/j.jebo.2012.03.008

Frijters, P., Haisken-DeNew, J. P., \& Shields, M. A. (2004). Investigating the patterns and determinants of life satisfaction in Germany following reunification. Journal of Human Resources, 39(3), 649-674. https://doi.org/10.3368/jhr.xxxix.3.649

Gasper, D. (2010). Understanding the diversity of conceptions of well-being and quality of life. Journal of Socio-Economics, 39(3), 351-360. https://doi.org/10.1016/j.socec.2009.11.006

Graham, C. (2011). The Pursuit of Happiness: An Economy of Well-Being. Washington DC: Brookings Institution Press.

Guven, C., \& Sørensen, B. E. (2012). Subjective Well-Being: Keeping Up with the Perception of the Joneses. In Social Indicators Research (Vol. 109). https://doi.org/10.1007/s11205-011-9910-X

Helliwell, J., Layard, R., \& Sachs, J. (2015). World Happiness Report 2015. Retrieved from http://eprints.lse.ac.uk/47487/

Hills, P., \& Argyle, M. (2001). Emotional stability as a major dimension of happiness. Personality and Individual Differences, 31(8), 1357-1364. https://doi.org/10.1016/S0191-8869(00)00229-4

$\mathrm{Hu}, \mathrm{F}$. (2013). Homeownership and Subjective Wellbeing in Urban China: Does Owning a House Make You Happier? Social Indicators Research, 110(3), 951-971. https://doi.org/10.1007/s11205-011-9967-6

Johns, H., \& Ormerod, P. (2007). Happiness, Economics, and Public Policy. https://doi.org/10.4337/9781782544371.00016

Kalyuzhnova, Y., \& Kambhampati, U. (2008). The determinants of individual happiness in Kazakhstan. Economic Systems, 32(3), 285-299. https://doi.org/10.1016/j.ecosys.2008.02.001

Knight, J., Song, L., \& Gunatilaka, R. (2009). Subjective well-being and its determinants in rural China. China Economic Review, 20(4), 635-649. https://doi.org/10.1016/j.chieco.2008.09.003

Landiyanto, E. A., Ling, J., Puspitasari, M., \& Irnanto, S. E. (2011). Wealth and Happiness : Empirical Evidence from Indonesia. Chulalongkorn Journal of Economics, 23, 1-17.

Oswald, A. J., \& Powdthavee, N. (2008). Does happiness adapt? A longitudinal 
study of disability with implications for economists and judges. Journal of Public Economics, 92(5-6), 1061-1077. https://doi.org/10.1016/j.jpubeco.2008.01.002

Parker, L., Watson, D., \& Webb, R. (2011). Family fortunes: Gender-based differences in the impact of employment and home characteristics on satisfaction levels. Journal of Socio-Economics, 40(3), 259-264. https://doi.org/10.1016/j.socec.2011.01.009

Pyndick, R. S., \& Rubinfeld, D. L. (2013). Microeconomics Eight Edition. New Jersey: Pearson.

Rahayu, T. P. (2016). Determinan kebahagiaan di indonesia. Jurnal Ekonomi Dan Bisnis, 19(1), 149-170.

Senasu, K., \& Singhapakdi, A. (2017). Determinants of happiness in Thailand: The moderating role of religiousness. Journal of Human Behavior in the Social Environment, $27(4)$ 270-290. https://doi.org/10.1080/10911359.2017.1279580

Sexton, R. L., Fortura, P. N., \& Kovacs, C. C. (2016). Exploring Microeconomics Fourth Canadian Edition. Canada: Nelson Education Ltd.

Shlay, A. B. (2006). "Low-income homeownership: American dream or delusion?" Urban Studies, 43(3), 511-531. https://doi.org/10.4324/9780203722671

Sirgy, M. J., Diener, E., Glatzer, W., Moum, T., Sprangers, M. A., Vogel, J., \& Veenhoven, R. (2012). The Psychology of Quality of Life: Hedonic WellBeing, Life Satisfaction, and Eudaimonia Second Edition. https://doi.org/10.1007/s11136-005-2383-0

Sohn, K. (2010). Considering Happiness For Economic Development : Determinants of Happiness in Indonesia (No. 10-09). Seoul.

Stutzer, A., \& Frey, B. S. (2006). Does marriage make people happy, or do happy people get married? Journal of Socio-Economics, 35(2), 326-347. https://doi.org/10.1016/j.socec.2005.11.043

Van Der Hulst, M. (2003). Long Workhours and Health. Scandinavian Journal of Work, Environment, \& Health, 29, 171-188.

Veenhoven, R. (2000). The Four Qualities of Life Ordering Concepts and Measures of the Good Life. Journal of Happiness Studies, 1, 1-39. https://doi.org/10.1007/978-94-007-5702-8_11 